\title{
The Relationship between Child Rearing Attitudes and Maternal Attachment Styles
}

\section{La relación entre las actitudes de crianza infantil y el apego materno}

\author{
Musa OYTUN', Azmiye YINAL ${ }^{2}$, Deniz ERDAĞ $\breve{~}^{3}$, Figen YAMAN \\ LESINGER ${ }^{4}$ \\ ${ }^{1}$ Musa OYTUN, Near East University, Faculty of Sports Scıence, \\ Lefkoşa/KKTC; Email: moytun@neu.edu.tr \\ ${ }^{2}$ Azmiye YINAL, European University of Lefke, Faculty of \\ Communication,Lefke/KKTC; Email: azmiye.ynl@gmail.com \\ ${ }^{3}$ Deniz ERDAĞ, Near East University, Faculty of Sports Scuence, \\ Lefkoşa/KKTC; Email: deniz.erdag@neu.edu.tr \\ ${ }^{4}$ Figen YAMAN LESINGER, Near East University, Faculty of Sports Science, \\ Lefkoşa/KKTC; Email: figen.yamanlesinger@neu.edu.tr
}

Enviado: 27 de junio de 2019

Aceptado para publicar: 30 de julio de 2019

Publicado: 8 de agosto de 2019

\begin{abstract}
In this study, the relationship between mothers' attachment styles and child rearing attitudes were investigated. Within the scope of the research, 100 participants filled out maternal adult attachment styles and surveys. In order to measure the research variables, "Demographic Information Form", "Experiences in Close Relationships Inventory" and "Child Rearing Attitudes Scale ölç were used. In the scope of the research, firstly, the differences of the scores regarding research variables in terms of demographic variables were examined. In addition, a correlation analysis was conducted between the subscales that measured the research variables. According to the findings of the study, mothers' attachment styles differ significantly in terms of income level. Besides, child development attitudes were significantly different in terms of demographic variables. There was a significant difference in child rearing attitudes in terms of education level, income level and number of children. According to the results of correlation analysis, there was a positive correlation between anxious attachment subscale and authoritarian attitude. The findings of the study are thought to be important in terms of providing information about the psychosocial status of the mother who is a leading figure in child development and providing care for the mothers who are pioneers in care and in light of the studies to be carried out in the further research.
\end{abstract}

Keywords: Attachment, Attachment Styles, Child Rearing Attitudes.

En este estudio, se investigó la relación entre los estilos de apego de las madres y las actitudes de crianza de los hijos. Dentro del alcance de la investigación, 100 participantes completaron estilos y encuestas de apego materno-adulto. Para medir las variables de investigación, se utilizaron "Formulario de información demográfica", "Inventario de experiencias en relaciones cercanas" y "Escala de actitudes de crianza infantil". En el alcance de la investigación, en primer lugar, se examinaron las diferencias de los puntajes con respecto a las variables de investigación en términos de variables demográficas. Además, se realizó un análisis de correlación entre las subescalas que midieron las variables de investigación. Según los hallazgos del estudio, los estilos de apego de las madres difieren significativamente en términos de nivel de ingresos. Además, las actitudes de desarrollo infantil fueron significativamente diferentes en términos de variables demográficas. Hubo una diferencia significativa en las actitudes de crianza de los niños en términos de nivel educativo, nivel de ingresos y número de niños. Según los resultados del análisis de correlación, hubo una correlación positiva entre la subescala de apego ansioso y la actitud autoritaria. Se cree que los hallazgos del estudio son importantes en términos de proporcionar información sobre el estado psicosocial de la madre, que es una figura destacada en el desarrollo del niño y brindar atención a las madres que son pioneras en el cuidado y a la luz de los estudios que se realizarán. fuera en la investigación adicional.

Palabras clave: apego, estilos de apego, actitudes de crianza infantil. 


\section{Introduction}

In order to survive, human offspring need more care than other species' offspring. (Soysal et al, 2005).Although the concept of attachment has been based on the physiological characteristics of infants for a long time based on this need, John Bowlby has revolutionized the psychology literature by explaining the link between the baby and the caregiver.(Sümer, Sayıl ve Berument, 2016).In the evolutionary process, Bowlby was believed not only for the physiological development of the baby, but also for the leaders of psychological development.(Shaw ve DeMaso, 2007; Villalobos Antúnez \& Bello, 2014). First of all, it was tried to understand why the babies who had to leave their mothers at an early age gave excessive stress reactionsHe concluded that this was an evolutionary function which increased the chances of survival not only in humans but also in other primates (Baykalova et al, 2018).

According to Bowlby, the child's attachment system constantly questions the availability of caregiverIf the caregiver is physically and emotionally accessible to the infant, the baby is comfortable to play and discover the environment, but in the opposite case, the balance is disturbed and an insecure structure develops. (Sümer et al, 2016; Badamchi Shabestari \& Malekzadeh, 2019). In addition to the effects of parenting behaviors on the attachment style of children, it is observed that the attachment styles of parents also affect the parental attitudes. Hazan and Shaver (1987) showed that attachment styles in adulthood stem from childhood acquired schemas.Parents try to meet their babies if they have these schemes that they brought from childhood. Parent attachment styles; both their child-rearing attitude and their attachment style.Attachment and child rearing attitudes are two issues that should not be considered independent from each other. (Algan ve Şendil, 2013; Kumar \& Gapta, 2017).

They raise their children by recognizing that all parents are aware of what their children will have when they grow up, what they will be like when they grow up, what moral values they will have and what kind of knowledge they will have.According to their moral views and values, they reinforce certain behaviors and punish some of them (Tahiroğlu et al, 2009; Ceisil, 2018).

As a role model, they aim to develop the correct behavior and they can contribute to their children by shaping the child's environment accordinglyEvery strategy chosen by the parents leads to different child rearing attitudes and behaviors (Margalit \& Raviv, 1984).

The attitudes of parents while raising their children not only affect the child's personality but also create an identification model for children.
The fact that the child will be a mother or father is closely related to the attitude he / she is exposed to (Eripek, 1989). The experiences of parents in their childhood and adolescence affect traumas' attitudes in raising their children (Feresin \& Močinić, 2017; Özgen, 2017; Eissazadeh \& Mostafavi, 2019).

The beginning of the parent child relationship is the connection between them.According to Ainsworth (1989), it is necessary to have a secure attachment for good parenting. It was observed that attachment styles of individuals affected both parenting attitudes and children's attachment (Ainsworth, 1989; Mostafavi, 2015).

\section{Aim Of The Study \\ The aim of this study is to examine the relationship between attachment styles and mothers' attitudes towards children between 24-36 months.In this way, the dominant attachment style that the mother brings from her past will measure what attitude she predominantly adopts in her relationship with her child.}

\section{Problem Status}

Is there a significant relationship between the dominant attachment style of mothers who have 24-36 months old children and the child rearing behaviors in their relationship with their children?

Is there a meaningful similarity in terms of child-rearing attitudes that mothers, who are predominantly anxious, agree with?

Is there a significant similarity in terms of child-rearing attitudes adopted by predominantly avoidant mothers?

Is there a significant relationship between mothers' attachment style and demographic characteristics?

Is there a significant relationship between the mothers' attitudes towards child rearing and their demographic characteristics?

\section{Importance Of Study}

The mother has a great role in a healthy psychosocial development. The more the child interacts with the mother, the stronger the personality development. As much as the mother gives confidence to the child and develops a positive attitude, it expresses the world inside the child as it is. In this way, being a mother with healthy attitudes seems to be possible with a healthy connection. Although there is a lot of research on this subject, researches in small age groups appear to be inadequate. This study, especially with mothers of babies aged 24-36 months, is important in terms of comparing demographic information with child rearing attitudes and attachment styles, as well as examining the relationship between attachment styles and child rearing attitudes. 


\section{Method}

\section{Universe and Sample}

The research is a descriptive study conducted with quantitative measurements. The participants were selected among the mothers of 24-36 months old children who were registered in various private kindergartens and kindergartens in Cyprus. The nursery choices were selected randomly without any criteria.Two different scales and sociodemographic data forms were applied to each mother who attended.

\section{Data Collection Tools}

Within the scope of the study, a random sampling was conducted and the survey was conducted with the approval of the participants' participation in the research. The data measurement tools determined by the researcher and applied to the participants are as follows:

\section{Socio-Demographic Form}

Socio-demographic variables studied; maternal age, educational status, working status, family income status, number of people at home, health status of mother physically and mentally, drug use, maternal mental health status of the mother and caregiver and mother, the age of the child is whether the child is a child planned and whether there is a relative who supports him in raising the child.

\section{Inventory of Experiences in Close Relationships - II (YIYYE-II)}

Experiences in Close Relationships-2 (YIYYE) "consists of a total of 36 items. Of these substances, 18 preventive attachment, while the remaining 18 measure the anxious attachment dimensions. Avoidance Attachment: Calculated by taking the average of the number of items. Concerned Attachment: Calculated by taking the average of the items with an odd number. Reverse-coded substances: 4, 8, 16, 17, 18, 20, 21, $22,24,26,30,32,34,36$. According to 7 rating method: $1=\mathrm{I}$ disagree $4=$ Neither agree nor disagree $7=$ I totally agree. The descriptive and confirmatory factor analyzes showed that the twofactor structure of the YIYE-II represents the avoidance and anxiety behaviors in attachmentThe relationship of the dimensions of avoidance and anxiety with other relevant variables supports the validity of YIYE -II. In addition, the dimensions measured by the YIYE-II were found to have a high level of internal consistency and test-retest reliability. According to the findings, it was suggested that researchers should use the YIYE-II which has higher measurement sitivity than other scales in the measurement of adult attachment. The test-retest reliability of the anxiety and avoidance dimensions of the YIYE-II was performed using data from 86 participants who filled the scaleAs a result of the analysis, it was found that the anxiety dimension was .82 and the avoidance dimension was test-retest reliability of .81 Both the avoidance and anxiety dimensions have high internal consistency and the Cronbach alpha coefficients are .90 and .86 for these dimensions, respectively. (Selçuk, Günaydın, Sümer ve Uysal, 2005).

\section{Child Rearing Attitudes Scale}

"Child Growth Attitude Scale" consists of 25 items in total. It measures democratic, protective, authoritarian and overly tolerant attitudes. The Child Growing Attitude Scale is a 4-point Likerttype scale. The scoring of the scale is between one and four. Each item is evaluated with always"four, ve often" three,"sometimes" two and, never Her points. The high score of each sub-dimension of the measurement tool consisting of four subdimensions, namely, democratic, authoritarian, protective and over-tolerant attitudes, shows that the characteristics of that dimension are high. In order to test the validity of the scale, there was the birth of an age, in the meantime a group of parents was formed, the validity was adjusted. The arada Maximum Likelihood Verification Factor Analysis in was used to test the eligibility index of the Child Rearing Attitude Scale. Es ranged from .71 .25 to .74 .42 . When the test-retest results were examined, the correlation coefficient was changed between .94 and .98 in the sub-dimensions. The results of the validity and reliability analyz, the Child Breeding Attitude Scale (CYTÖ), had sufficient psychometric properties (Mendi ve ark, 2016; Mohammad, 2017).

\section{Data Analysis}

Within the scope of the research, data obtained from mothers were analyzed and applied statistical analysis methods. Statistical Package for Social Sciences (SPSS) was used to analyze the problem of the study. The research includes descriptive, comparative and relational analysis methods. In the study, frequency distributions of demographic variables were given and compared with research variables. In the comparison of the demographic variables of the two groups with the research variables, the demographic variables do not show normal distribution with the research variables and them Mann Whitney U test değişken is presented. "Kruskal Wallis Homogeneity Test was performed for demographic variables containing more than two categories.

\section{Results}

Research, mothers' attachment styles and child rearing attitudes were examinedFirst, the frequency distributions of the demographic variables of the participants are given in Table 1 . 
In addition, in terms of demographic variables, için Anxiety eller and Avoidance scores, which are sub-dimensions of) Inventory of Experiences in Close Relationships - II (YIYYE-II) ografik, were used to measure adult attachment models. In order to examine child rearing attitudes, scores of democratic, authoritarian, protective and overtolerant attitudes, which are sub-dimensions of Child Rearing Attitudes Scale, were compared. Non-homogeneous measurements of groups of demographic variables, non-parametric measurements.In order to compare the demographic variables of both groups, Mann Whitney $U$ test was used in this research "Kruskal Wallis Homogeneity test ategor was used to compare demographic variables with more than two categories with research variables. In comparison analysis, the significance value was taken as 0.05. However, Pearson Correlation was conducted to examine the relationship between the sub-dimensions that measure the research variables. The significance value was taken as 0.01 and 0.05 .

Table 1. Frequency Distribution of Demographic Variables

\begin{tabular}{|c|c|c|c|}
\hline Demographic Variables & $(\mathrm{N}=100)$ & $\mathrm{N}$ & $\%$ \\
\hline Education & primary school & 13 & 13.0 \\
\hline & secondary school & 10 & 10.0 \\
\hline & high school & 22 & 22.0 \\
\hline & $\mathrm{BA}$ & 45 & 45.0 \\
\hline & MA & 10 & 10.0 \\
\hline & Total & 100 & 100.0 \\
\hline Working Status & Working & 49 & 49.0 \\
\hline & Unemployed & 51 & 51.0 \\
\hline & Total & 100 & 100.0 \\
\hline Income & Low & 5 & 5.0 \\
\hline & Medium & 46 & 46.0 \\
\hline & High & 49 & 49.0 \\
\hline & Total & 100 & 100.0 \\
\hline Family Type & Mainfamily & 85 & 85.0 \\
\hline & Extended family & 10 & 10.0 \\
\hline & Shredded falimy & 5 & 5.0 \\
\hline & Total & 100 & 100.0 \\
\hline Psychological Problem & Yes & 15 & 15.0 \\
\hline & No & 85 & 85.0 \\
\hline & Total & 100 & 100.0 \\
\hline Psychiatric Medication & Yes & 4 & 4.0 \\
\hline & No & 96 & 96.0 \\
\hline & Total & 100 & 100.0 \\
\hline Children & 1 & 33 & 33.0 \\
\hline & 2 & 51 & 51.0 \\
\hline & 3 & 16 & 16.0 \\
\hline & Total & 100 & 100.0 \\
\hline Childbrank & 1 & 33 & 33.0 \\
\hline & 2 & 53 & 53.0 \\
\hline & 3 & 14 & 14.0 \\
\hline Having children & Planned & 88 & 88.0 \\
\hline & Unplanned & 12 & 12.0 \\
\hline & Total & 100 & 100.0 \\
\hline Child care suppot & Supported & 47 & 47.0 \\
\hline & No Supported & 53 & 53.0 \\
\hline & Total & 100 & 100.0 \\
\hline
\end{tabular}

When the frequency distributions of demographic variables are examined in Table 1, 100 people participated in the study. $13 \%$ are primary school graduates, $10 \%$ are secondary school graduates, 
$22 \%$ are high school graduates, $45 \%$ are university graduates and $10 \%$ are graduate. $49 \%$ of the work is done; $51 \%$ reported not working. $5 \%$ of the rankings by income level were low income level, $46 \%$ middle income level and $49 \%$ high income level.85\% of the family is in the main family, $10 \%$ is in the extended family, and $5 \%$ of the broken family is specified.It was stated that $15 \%$ of the participants had a psychological disorder and $85 \%$ did not have any psychological disorder. $4 \%$ of the participants stated that they used psychiatric drugs and $96 \%$ did not use them.According to the number of children, the rate of children with 1 child is $33 \%$, with 2 children $51 \%$, and $16 \%$ of children with 3 or more children.According to the children's order, the first child of the participants was $33 \%$, the second child was $53 \%$ and the third child was $14 \%$. $88 \%$ of the respondents reported that they had a child in a planned manner, and $12 \%$ answered that they were not plannedIt was stated that $47 \%$ of the participants had support in child care and $53 \%$ did not have any support.

\section{Comparison of Adult Attachment Models for} Demographic Variables

I Mann Whitney U test II for dual group variables were compared with II Anxiety"andAvoidancescores, which are subdimensions of"Inventory of Experiences in Close Relationships - II (YIYE-II) which are used to measure mothers' attachment styles in terms of demographic variables; Hom Kruskal Wallis Homogeneity Test was used for multiple group variables. The significance value was taken as 0.05 .

Table 2. Comparison of Adult Attachment Models in Terms of Working State Variable

\begin{tabular}{lllllll}
\hline YIYE & $\begin{array}{c}\text { Sub-Working } \\
\text { Dimensions }\end{array}$ & $\mathrm{N}$ & Average & Total & $\mathrm{U}$ & $\mathrm{p}$ \\
\hline \multirow{3}{*}{ Avoidance } & Working & 49 & 51.15 & 2506.50 & & \\
& Not working & 51 & 49.87 & 2543.50 & 1217,500 &, 825 \\
& Total & 100 & & & & \\
\multirow{2}{*}{ Anxiety } & Working & 49 & 47.26 & 2315.50 & & \multirow{2}{*}{273} \\
& Not working & 51 & 53.62 & 2734.50 & & \\
\hline
\end{tabular}

According to the results of the çalışma Mann Whitney $\mathrm{U}$ test conducted in order to compare the attachment styles of mothers in terms of working status in Table 2, it was found that anxiety and avoidance sub-dimensions did not differ significantly in terms of working status $(p>0,05)$.

Table 3. Comparison of Adult Attachment Models for Psychological Disorder Variables

\begin{tabular}{lllllll}
\hline $\begin{array}{l}\text { YIYE } \\
\text { Dimensions }\end{array}$ & $\begin{array}{c}\text { Sub-psychological } \\
\text { discomfort }\end{array}$ & $\mathrm{N}$ & Average & Total & $\mathrm{U}$ & $\mathrm{p}$ \\
\hline \multirow{4}{*}{ Avoidance } & Yes & 15 & 43.40 & 651.00 & & \\
& No & 85 & 51.75 & 4399.00 & 531,000 &, 304 \\
& Total & 100 & & & & \\
\multirow{5}{*}{ Anxiety } & Yes & 15 & 45.13 & 677.00 & & \\
& No & 85 & 51.45 & 4373.00 & 557,000 &, 437 \\
& Total & 100 & & & & \\
\hline
\end{tabular}

According to the results of the Mann Whitney U test conducted in order to compare the attachment styles of mothers in terms of working status in
Table 2, it was found that anxiety and avoidance sub-dimensions did not differ significantly in terms of working status. $(p>0,05)$.

Table 4. Comparison of Adult Attachment Models for Psychiatric Drug Variables

\begin{tabular}{|c|c|c|c|c|c|c|}
\hline $\begin{array}{l}\text { YIYE Sul } \\
\text { Dimensions }\end{array}$ & $\begin{array}{l}\text {-Psychiatric } \\
\text { medicament }\end{array}$ & $\mathrm{N}$ & Average & Total & $\mathrm{U}$ & $\mathrm{p}$ \\
\hline \multirow{3}{*}{ Avoidance } & Yes & 4 & 46.38 & 185.50 & & \\
\hline & No & 96 & 50.67 & 4864.50 & 175,500 &, 772 \\
\hline & Total & 100 & & & & \\
\hline & Yes & 4 & 41.88 & 167.50 & & \\
\hline \multirow[t]{2}{*}{ Anxiety } & No & 96 & 50.86 & 4882.50 & 157,500 &, 544 \\
\hline & Total & 100 & & & & \\
\hline
\end{tabular}

According to the results of the Mann Whitney $U$ test conducted in order to compare the attachment styles of mothers in terms of psychiatric drug use variable, it was determined that anxiety and 
avoidance sub-dimensions did not differ $(\mathrm{p}>0,05)$. significantly in terms of psychiatric drug variable

Table 5. Comparison of Adult Connectivity Models in terms of Expectation to Have Children

\begin{tabular}{lllllll}
\hline $\begin{array}{l}\text { YIYE } \\
\text { Dimensions }\end{array}$ & Planed child & $\mathrm{N}$ & Average & Total & $\mathrm{U}$ & $\mathrm{p}$ \\
\hline \multirow{2}{*}{ Avoidance } & planned & 88 & 50.38 & 4433.50 & & \\
& Unplanned & 12 & 51.38 & 616.50 & 517,500 & \multirow{2}{*}{, 911} \\
& Total & 100 & & & & \\
\multirow{2}{*}{ Anxiety } & supported & 88 & 51.07 & 4494.00 & & \multirow{2}{*}{596} \\
& No Supported & 12 & 46.33 & 556.00 & 478,000 &, 560 \\
& Total & 100 & & & & \\
\hline
\end{tabular}

According to the results of the sah Mann Whitney $\mathrm{U}$ test bek conducted in order to compare the attachment styles of mothers in terms of expectation of having children in Table 5, it was found that anxiety and avoidance sub-dimensions did not differ significantly in terms of expectation of having children $(\mathrm{p}>0,05)$.

Table 6. Comparison of Adult Attachment Models in Support of Child Care Variables

\begin{tabular}{lllllll}
\hline YIYE & Sub-in terms & of & \multirow{2}{*}{ Average } & Total & $\mathrm{U}$ & $\mathrm{p}$ \\
Dimensions & support & & & & \\
\hline \multirow{2}{*}{ Avoidance } & support & 47 & 53.50 & 2514.50 & & \\
& no support & 53 & 47.84 & 2535.50 & 1104,500 & \multirow{2}{*}{330} \\
& Total & 100 & & & & \\
\multirow{4}{*}{ Anxiety } & support & 47 & 48.05 & 2258.50 & & \multirow{2}{*}{427} \\
& no support & 53 & 52.67 & 2791.50 & 1130,500 &, 427 \\
& Total & 100 & & & & \\
\hline
\end{tabular}

ccording to the results of the lar Mann Whitney U test conducted in order to compare the attachment styles of the mothers in terms of the support variable in child care in Table 6, it was found that the anxiety and avoidance sub-dimensions did not differ significantly in terms of support in child care $(p>0,05)$.

Table 7. Comparison of Adult Attachment Models in terms of Education Level Variable

\begin{tabular}{|c|c|c|c|c|c|c|}
\hline $\begin{array}{l}\text { YIYE } \\
\text { Dimensions }\end{array}$ & Sub- Education & $\mathrm{N}$ & Average & $\mathrm{Z}$ & $\mathrm{sd}$ & $\mathrm{p}$ \\
\hline \multirow{6}{*}{ Avoidance } & Primary school & 13 & 64.38 & \multirow{6}{*}{4,997} & \multirow{5}{*}{4} & \multirow{5}{*}{,288 } \\
\hline & middle School & 10 & 51.20 & & & \\
\hline & high school & 22 & 50.91 & & & \\
\hline & License & 45 & 44.93 & & & \\
\hline & Master & 10 & 55.90 & & & \\
\hline & Total & 100 & & & & \multirow{7}{*}{,097 } \\
\hline \multirow{6}{*}{ Anxiety } & primary school & 13 & 69.04 & \multirow{6}{*}{7,858} & \multirow{6}{*}{4} & \\
\hline & middle School & 10 & 53.95 & & & \\
\hline & high school & 22 & 52.25 & & & \\
\hline & License & 45 & 45.60 & & & \\
\hline & Master & 10 & 41.15 & & & \\
\hline & Total & 100 & & & & \\
\hline
\end{tabular}

According to the results of 'Kruskal Wallis Wall conducted in order to compare the attachment styles of mothers in terms of education level variable in Table 7 , it was found that anxiety and avoidance sub-dimensions did not differ significantly in terms of educational level $(\mathrm{p}>0,05)$.

Table 8. Comparison of Adult Attachment Models for Income Level Variables 


\begin{tabular}{lllllll}
\hline YIYE & \multicolumn{2}{c}{ Sub- } \\
Dimensions & Income rate & $\mathrm{N}$ & Average & $\mathrm{Z}$ & sd & $\mathrm{p}$ \\
\hline \multirow{3}{*}{ Avoidance } & Low & 5 & 73.30 & & & \\
& Middle & 46 & 46.99 & & & \multirow{6}{*}{148} \\
& High & 49 & 51.47 & 3,821 & 2 & \\
& Total & 100 & & & & \\
\multirow{4}{*}{ Anxiety } & Low & 5 & 81.90 & & & \\
& Middle & 46 & 48.65 & 6,174 & 2 & $\mathbf{0 4 6}^{*}$ \\
& High & 49 & 49.03 & & & \\
\hline
\end{tabular}

According to the results of eni Kruskal Wallis"conducted for comparing mothers' attachment styles in terms of income level variable in Table 8 , it was found that avoidance sub-dimension did not differ significantly in terms of income level ( $p>0.05)$. However, anxiety subscale was found to be significantly different according to income level ( $U=6,174 ; \mathrm{p}<0,05)$. The lowerthe level of income, the more anxious the attachment style is.

Table 9. Comparison of Adult Attachment Models in terms of Family Type Variables

\begin{tabular}{|c|c|c|c|c|c|c|}
\hline $\begin{array}{l}\text { YIYE } \\
\text { Dimensions }\end{array}$ & Sub-Family Type & $\mathrm{N}$ & Average & $\mathrm{Z}$ & sd & $\mathrm{p}$ \\
\hline \multirow{4}{*}{ Avoidance } & Main family & 85 & 51.56 & \multirow{4}{*}{1,231} & \multirow{4}{*}{2} & \multirow{3}{*}{, 540} \\
\hline & Extended family & 10 & 40.85 & & & \\
\hline & Shredded falimy & 5 & 51.80 & & & \\
\hline & Total & 100 & & & & \\
\hline \multirow{3}{*}{ Anxiety } & Main family & 85 & 50.45 & \multirow{3}{*}{3,884} & \multirow{3}{*}{2} & \multirow{3}{*}{, 143} \\
\hline & Extended family & 10 & 61.20 & & & \\
\hline & $\begin{array}{l}\text { Shredded falimy } \\
\text { Total }\end{array}$ & $\begin{array}{l}5 \\
100\end{array}$ & 29.90 & & & \\
\hline
\end{tabular}

In Table 9, according to the results of Kruskal Wallis Wall in order to compare the attachment styles of mothers in terms of family type variables, it was found that the anxiety and avoidance sub-dimensions did not differ significantly in terms of family type $(p>0,05)$.

Table 10. Comparison of Adult Connectivity Models in terms of Number of Children

\begin{tabular}{|c|c|c|c|c|c|c|}
\hline $\begin{array}{l}\text { YIYE Su } \\
\text { Dimensions }\end{array}$ & Role $n$ & & Average & Z & $\mathrm{Sd}$ & $\mathrm{p}$ \\
\hline & 1 & 33 & 53.39 & & & \\
\hline Avoidance & 2 & 51 & 49.59 & 2,185 & 2 & ,335 \\
\hline & 3 & 16 & 40.00 & & & \\
\hline & Total & 100 & & & & \\
\hline & 1 & 33 & 44.47 & & & \\
\hline & 2 & 51 & 52.78 & 1,715 & 2 & ,424 \\
\hline Anxiety & 3 & 16 & 49.39 & & & \\
\hline & Total & 100 & & & & \\
\hline
\end{tabular}

In Table 10, according to the results of "Kruskal Wallis Wall conducted in order to compare the attachment styles of mothers in terms of the number of children, it was found that the anxiety and avoidance sub-dimensions did not differ significantly in terms of the number of children. $(p>0,05)$.

Table 11. Comparison of Adult Attachment Models in terms of Child Birth Sequence

\begin{tabular}{lllllll}
\hline $\begin{array}{l}\text { YIYE } \\
\text { Dimensions }\end{array}$ & $\begin{array}{c}\text { Rumber } \\
\text { Number }\end{array}$ & $\mathrm{N}$ & Average & $\mathrm{Z}$ & $\mathrm{sd}$ & $\mathrm{p}$ \\
\hline \multirow{3}{*}{ Avoidance } & 1 & 33 & 55.38 & & & \\
& 2 & 53 & 51.37 & 4,622 & 2 &, 099 \\
& 3 & 14 & 35.71 & & & \\
Anxiety & Total & 100 & & & & \\
\hline
\end{tabular}




\begin{tabular}{llllll}
\hline 2 & 53 & 55.58 & 3,836 & 2 &, 147 \\
3 & 14 & 40.82 & & & \\
Total & 100 & & & & \\
\hline
\end{tabular}

In Table 11, according to the results of Kruskal Wallis performed for comparing mothers' attachment styles in terms of child birth order variable, it was determined that anxiety and avoidance sub-dimensions did not differ significantly in terms of child birth order variable. $(\mathrm{p}>0,05)$.

\section{Comparison of Child Rearing Attitudes with Demographic Variables}

In the research, the scores of the democratic, authoritarian, protective and over-tolerant attitudes, which are sub-dimensions of the Child Rearing Attitudes Scale, were compared in order to examine child rearing attitudes. Nonparametric measurements were used because of the homogeneous distribution of demographic variables. The Mann Whitney $U$ test Whit was used to compare the demographic variables of the two groups with the research variables. Kruskal Wallis Homogeneity test ografik was applied for the demographic variables containing multiple groups. The significance value was taken as 0.05 .

Table 12. Comparison of Child Rearing Attitudes in Terms of Working State Variable

\begin{tabular}{|c|c|c|c|c|c|c|}
\hline Attitudes of Growing Children & Operating sta & & Average & Total & $\mathrm{U}$ & $\mathrm{p}$ \\
\hline \multirow[b]{3}{*}{ Democratic } & working & 49 & 53.89 & 2640.50 & \multirow{3}{*}{1083.500} & \multirow{3}{*}{250} \\
\hline & \multirow[t]{2}{*}{ Not working } & & & & & \\
\hline & & 51 & 47.25 & 2409.50 & & \\
\hline \multirow{4}{*}{ Protective } & \multirow{3}{*}{$\begin{array}{l}\text { Total } \\
\text { working } \\
\text { Not working }\end{array}$} & 100 & & & \multirow[b]{3}{*}{1098.500} & \multirow[b]{3}{*}{.295} \\
\hline & & 49 & 53.58 & 2625.50 & & \\
\hline & & 51 & 47.54 & 2424.50 & & \\
\hline & \multirow{3}{*}{$\begin{array}{l}\text { Total } \\
\text { working } \\
\text { Not working }\end{array}$} & 100 & & & \multirow[b]{3}{*}{1187.500} & \multirow[b]{3}{*}{.666} \\
\hline \multirow{3}{*}{ Authoritarian } & & 49 & 49.23 & 2412.50 & & \\
\hline & & 51 & 51.72 & 2637.50 & & \\
\hline & Total & 100 & & & & \multirow{4}{*}{.574} \\
\hline \multirow{3}{*}{ Extremely tolerant } & working & 49 & 52.14 & 2555.00 & & \\
\hline & Not working & 51 & 48.92 & 2495.00 & 1169.000 & \\
\hline & Total & 100 & & & & \\
\hline
\end{tabular}

According to the results of the Mann Whitney U test conducted in order to compare the mothers' attitudes towards the study of mothers in terms of working status variable, it was found that child rearing attitudes sub-dimensions did not differ significantly $(\mathrm{p}>0,05)$.

Table 13. Comparison of Attitudes of Child Rearing Attitudes in Terms of Psychological Disorder

\begin{tabular}{|c|c|c|c|c|c|c|}
\hline $\begin{array}{l}\text { Attitudes } \\
\text { Growing } \\
\text { Children }\end{array}$ & $\begin{array}{l}\text { Psychological } \\
\text { Problems }\end{array}$ & $\mathrm{N}$ & Average & Total & $\mathrm{U}$ & $\mathrm{p}$ \\
\hline \multirow{3}{*}{ Democratic } & Yes & 15 & 50.57 & 758.50 & \multirow{3}{*}{636,500} & \multirow{3}{*}{,992 } \\
\hline & No & 85 & 50.49 & 4291.50 & & \\
\hline & Total & 100 & & & & \\
\hline \multirow{3}{*}{ Protective } & Yes & 15 & 52.80 & 792.00 & \multirow{3}{*}{603,000} & \multirow{3}{*}{,738 } \\
\hline & No & 85 & 50.09 & 4258.00 & & \\
\hline & Total & 100 & & & & \\
\hline \multirow{3}{*}{ Authoritarian } & Yes & 15 & 49.50 & 742.50 & \multirow{3}{*}{622,500} & \multirow{3}{*}{, 884} \\
\hline & No & 85 & 50.68 & 4307.50 & & \\
\hline & Total & 100 & & & & \\
\hline \multirow{3}{*}{$\begin{array}{l}\text { Extremely } \\
\text { tolerant }\end{array}$} & Yes & 15 & 53.93 & 809.00 & \multirow{3}{*}{586,000} & \multirow{3}{*}{,615 } \\
\hline & No & 85 & 49.89 & 4241.00 & & \\
\hline & Total & 100 & & & & \\
\hline
\end{tabular}


attitudes towards parenting in terms of the psychological disturbance variable in Table 13, it was found that child rearing attitudes sub- dimensions did not differ significantly in terms of psychological disturbance variable $(\mathrm{p}>0,05)$.

Table 14. Comparison of Attitudes of Child Rearing Attitudes in terms of Psychiatric Drug Use Variables

\begin{tabular}{|c|c|c|c|c|c|c|}
\hline $\begin{array}{l}\text { Attitudes } \\
\text { Growing } \\
\text { Children }\end{array}$ & $\begin{array}{l}\mathrm{f}_{\text {Psychiatric }} \\
\text { medication use }\end{array}$ & $\mathrm{N}$ & Average & Total & $\mathrm{U}$ & $\mathrm{P}$ \\
\hline & Yes & 4 & 56.38 & 225.50 & & \\
\hline \multirow[t]{3}{*}{ Demokratic } & No & 96 & 50.26 & 4824.50 & 168,500 & 678 \\
\hline & Total & 100 & & & & \\
\hline & Yes & 4 & 54.38 & 217.50 & & \\
\hline \multirow[t]{3}{*}{ Protective } & No & 96 & 50.34 & 4832.50 & 176,500 & ,784 \\
\hline & Total & 100 & & & & \\
\hline & Yes & 4 & 45.50 & 182.00 & & \\
\hline \multirow[t]{3}{*}{ Authoritarian } & No & 96 & 50.71 & 4868.00 & 172,000 &, 723 \\
\hline & Total & 100 & & & & \\
\hline & Yes & 4 & 58.00 & 232.00 & & \\
\hline \multirow[t]{2}{*}{ Over*tolerant } & No & 96 & 50.19 & 4818.00 & 162,000 & ,593 \\
\hline & Total & 100 & & & & \\
\hline
\end{tabular}

According to the results of the Mann Whitney U test conducted in order to compare the mothers' attitudes towards child rearing in terms of the psychiatric drug variable, it was found that child rearing attitudes sub-dimensions did not differ significantly in terms of psychiatric drug variable $(\mathrm{p}>0.05)$.

Tablo1. Comparison of the Attitudes of Child Raising Attitudes

\begin{tabular}{|c|c|c|c|c|c|c|}
\hline $\begin{array}{l}\text { Attitudes } \\
\text { Growing } \\
\text { Children }\end{array}$ & $\begin{array}{l}\text { Planning to } \\
\text { a child }\end{array}$ & have $_{N}$ & Average & Total & $\mathrm{U}$ & $\mathrm{p}$ \\
\hline \multirow{3}{*}{ Democratic } & planned & 88 & 51.23 & 4508.00 & \multirow{3}{*}{464,000} & \multirow{3}{*}{,495 } \\
\hline & unplanned & 12 & 45.17 & 542.00 & & \\
\hline & Total & 100 & & & & \\
\hline \multirow{3}{*}{ Protective } & planned & 88 & 51.18 & 4504.00 & \multirow{3}{*}{468,000} & \multirow{3}{*}{, 522} \\
\hline & unplanned & 12 & 45.50 & 546.00 & & \\
\hline & Total & 100 & & & & \\
\hline \multirow{3}{*}{ Authoritarian } & planned & 88 & 51.26 & 4510.50 & \multirow{3}{*}{461,500} & \multirow{3}{*}{,477 } \\
\hline & unplanned & 12 & 44.96 & 539.50 & & \\
\hline & Total & 100 & & & & \\
\hline \multirow{3}{*}{$\begin{array}{l}\text { Extremely } \\
\text { tolerant }\end{array}$} & planned & 88 & 50.11 & 4410.00 & \multirow{3}{*}{494,000} & \multirow{3}{*}{,715 } \\
\hline & unplanned & 12 & 53.33 & 640.00 & & \\
\hline & Total & 100 & & & & \\
\hline
\end{tabular}

According to the results of the Mann Whitney U test ibi conducted in order to compare the mothers' attitudes towards child rearing in terms of the plan of having children in Table 15, it was found that child rearing attitudes sub-dimensions did not differ significantly in terms of the plan of having children. $(p>0,05)$.

Table 16. Comparison of Child Rearing Attitudes in Terms of Education Level Variablev

\begin{tabular}{|c|c|c|c|c|c|c|}
\hline $\begin{array}{l}\text { Attitudes } \\
\text { Growing } \\
\text { Children }\end{array}$ & ${ }^{o f}$ Education & $\mathrm{N}$ & Average & Z & $\mathrm{Sd}$ & $\mathrm{p}$ \\
\hline & Primary school & 13 & 34.12 & & & \\
\hline & Middle School & 10 & 28.35 & & & \\
\hline Democratic & High school & 22 & 48.09 & 15,663 & 4 & ,004 \\
\hline \multirow[t]{3}{*}{ Protective } & License & 45 & 60.30 & & & \\
\hline & Graduation & 10 & 55.15 & & & \\
\hline & Total & 100 & & & & \\
\hline Authoritarian & Primary school & 13 & 44.38 & & & \\
\hline Extremely & Middle School & 10 & 46.00 & & & \\
\hline
\end{tabular}




\begin{tabular}{|c|c|c|c|c|c|}
\hline \multirow[t]{6}{*}{ tolerant } & High school & 2253.39 & \multirow[t]{6}{*}{2,824} & \multirow[t]{6}{*}{4} & \multirow[t]{6}{*}{,588 } \\
\hline & License & $45 \quad 49.22$ & & & \\
\hline & Graduation & $10 \quad 62.35$ & & & \\
\hline & Total & 100 & & & \\
\hline & Primary school & $13 \quad 52.69$ & & & \\
\hline & Middle School & $10 \quad 56.85$ & & & \\
\hline Democratic & High school & $22 \quad 49.80$ & \multirow[t]{7}{*}{, 745} & \multirow[t]{7}{*}{4} & \multirow[t]{7}{*}{,946 } \\
\hline \multirow[t]{5}{*}{ Protective } & License & $45 \quad 48.74$ & & & \\
\hline & Graduation & $10 \quad 50.75$ & & & \\
\hline & Total & 100 & & & \\
\hline & Primary school & $13 \quad 51.62$ & & & \\
\hline & Middle School & $10 \quad 52.15$ & & & \\
\hline \multirow{4}{*}{ Authoritarian } & High school & $22 \quad 59.27$ & & & \\
\hline & License & $45 \quad 42.91$ & \multirow[t]{3}{*}{6,956} & \multirow[t]{3}{*}{4} & \multirow[t]{3}{*}{, 138} \\
\hline & Graduation & $10 \quad 62.25$ & & & \\
\hline & Total & 100 & & & \\
\hline
\end{tabular}

In Table 16, according to the results of or Kruskall Wallis homogeneity test conducted to compare mothers' attitudes towards education in terms of education level variable, it was determined that the dimensions of child rearing attitudes, which are child-rearing attitudes with respect to education level variable, did not differ significantly in terms of child-rearing attitudes ( $p>$
0, 05). Democratic attitude differs significantly from education level; democratic attitude scores of mothers with postgraduate degrees were found to be significantly higher than other attitudes $(\mathrm{Z}=$ $15,663 ; \mathrm{p}<0.05)$. As the level of education increases, the attitude of democratic attitude increases.

Table 17. Comparison of Child Rearing Attitudes in Terms of Income Level Variable

\begin{tabular}{|c|c|c|c|c|c|c|}
\hline $\begin{array}{l}\text { Attitudes } \\
\text { Growing } \\
\text { Children }\end{array}$ & Income rate & $\mathrm{N}$ & Average & Z & $\mathrm{Sd}$ & $\mathrm{p}$ \\
\hline \multirow{4}{*}{ Demokratic } & Low & 5 & 53.20 & \multirow{4}{*}{3,154} & \multirow{4}{*}{2} & \multirow{4}{*}{,207 } \\
\hline & Middle & 46 & 44.97 & & & \\
\hline & High & 49 & 55.42 & & & \\
\hline & Total & 100 & & & & \\
\hline \multirow{4}{*}{ Protective } & Low & 5 & 46.50 & \multirow{4}{*}{6,189} & \multirow{4}{*}{2} & \multirow{4}{*}{, $045 *$} \\
\hline & Middle & 46 & 43.17 & & & \\
\hline & High & 49 & 57.79 & & & \\
\hline & Total & 100 & & & & \\
\hline \multirow{4}{*}{ Otoriter } & Low & 5 & 46.50 & \multirow{4}{*}{, 480} & \multirow{4}{*}{2} & \multirow{4}{*}{,786 } \\
\hline & Middle & 46 & 48.84 & & & \\
\hline & High & 49 & 52.47 & & & \\
\hline & Total & 100 & & & & \\
\hline \multirow{4}{*}{ Over-tolerant } & Low & 5 & 52.00 & \multirow{4}{*}{1,368} & \multirow{4}{*}{2} & \multirow{4}{*}{, 505} \\
\hline & Middle & 46 & 46.89 & & & \\
\hline & High & 49 & 53.73 & & & \\
\hline & Total & 100 & & & & \\
\hline
\end{tabular}

$* p<0, \overline{05}$

In Table 17, according to the results of or Kruskall Wallis homogeneity test conducted to compare the mothers' attitudes of raising children in terms of the income level variable, it was found that the dimensions of child-rearing attitudes which are child-rearing attitudes with respect to the income level variable did not differ significantly in the dimensions of democratic, authoritarian and over- tolerant child rearing attitudes $(\mathrm{p}>0,05)$. The protective attitude is significantly different from the income level; democratic attitude scores of mothers with high income level were found to be significantly higher than other attitudes $(Z=$ $6,189 ; \mathrm{p}<0,05)$. Mothers with high income levels were found to adopt more protective attitudes.

Table 18. Comparison of Child Rearing Attitudes in Terms of Family Type Variables 


\begin{tabular}{|c|c|c|c|c|c|c|}
\hline $\begin{array}{l}\text { Attitudes of Growing } \\
\text { Children }\end{array}$ & Family Type & $\mathrm{N}$ & Average & $\mathrm{Z}$ & $\mathrm{Sd}$ & $\mathrm{p}$ \\
\hline \multirow{4}{*}{ Democratic } & Main family & 85 & 50.76 & \multirow{4}{*}{,660 } & \multirow{4}{*}{2} & \multirow{4}{*}{,719 } \\
\hline & $\begin{array}{l}\text { Extended } \\
\text { family }\end{array}$ & 10 & 44.90 & & & \\
\hline & $\begin{array}{l}\text { Shredded } \\
\text { falimy }\end{array}$ & 5 & 57.30 & & & \\
\hline & Total & 100 & & & & \\
\hline \multirow{4}{*}{ Protective } & Main family & 85 & 50.79 & \multirow{4}{*}{5,006} & \multirow{4}{*}{2} & \multirow{4}{*}{, 082} \\
\hline & $\begin{array}{l}\text { Extended } \\
\text { family }\end{array}$ & 10 & 37.15 & & & \\
\hline & $\begin{array}{l}\text { Shredded } \\
\text { falimy }\end{array}$ & 5 & 72.30 & & & \\
\hline & Total & 100 & & & & \\
\hline \multirow{4}{*}{ Otoriter } & Main family & 85 & 50.71 & \multirow{4}{*}{,097 } & \multirow{4}{*}{2} & \multirow{4}{*}{,953 } \\
\hline & $\begin{array}{l}\text { Extended } \\
\text { family }\end{array}$ & 10 & 47.95 & & & \\
\hline & $\begin{array}{l}\text { Shredded } \\
\text { falimy }\end{array}$ & 5 & 52.00 & & & \\
\hline & Total & 100 & & & & \\
\hline \multirow{4}{*}{ Over-tolerant } & Main family & 85 & 50.59 & \multirow{4}{*}{,368 } & \multirow{4}{*}{2} & \multirow{4}{*}{, 832} \\
\hline & $\begin{array}{l}\text { Extended } \\
\text { family }\end{array}$ & 10 & 53.15 & & & \\
\hline & $\begin{array}{l}\text { Shredded } \\
\text { falimy }\end{array}$ & 5 & 43.70 & & & \\
\hline & Total & 100 & & & & \\
\hline
\end{tabular}

According to the results of the Kruskall Wallis homogeneity test conducted in order to compare the mothers' attitudes towards child rearing in terms of the family type variable, it was found that the dimensions of child rearing attitudes did not differ significantly in terms of family type $(\mathrm{p}>0,05)$.

Table 19. Comparison of Child Breeding Attitudes in terms of Number of Children

\begin{tabular}{|c|c|c|c|c|c|c|}
\hline $\begin{array}{l}\text { Attitudes } \\
\text { Growing } \\
\text { Children } \\
\end{array}$ & $\begin{array}{l}\text { Number } \\
\text { children }\end{array}$ & $\begin{array}{l}\text { of } \\
\mathrm{N} \\
\end{array}$ & Average & Z & $\mathrm{Sd}$ & $\mathrm{p}$ \\
\hline \multirow{4}{*}{ Democratic } & 1 & 33 & 50.71 & \multirow{4}{*}{1,237} & \multirow{4}{*}{2} & \multirow{4}{*}{, 539} \\
\hline & 2 & 51 & 50.85 & & & \\
\hline & 3 & 16 & 41.71 & & & \\
\hline & Total & 100 & & & & \\
\hline \multirow{4}{*}{ Protective } & 1 & 33 & 57.98 & \multirow{4}{*}{6,964} & \multirow{4}{*}{2} & \multirow{4}{*}{,031* } \\
\hline & 2 & 51 & 48.09 & & & \\
\hline & 3 & 16 & 34.64 & & & \\
\hline & Total & 100 & & & & \\
\hline \multirow{4}{*}{ Authoritarian } & 1 & 33 & 45.27 & \multirow{4}{*}{1,233} & \multirow{4}{*}{2} & \multirow{4}{*}{, 540} \\
\hline & 2 & 51 & 51.03 & & & \\
\hline & 3 & 16 & 53.89 & & & \\
\hline & Total & 100 & & & & \\
\hline \multirow{4}{*}{ Over-tolerant } & 1 & 33 & 49.95 & \multirow{4}{*}{,497 } & \multirow{4}{*}{2} & \multirow{4}{*}{, 780} \\
\hline & 2 & 51 & 50.54 & & & \\
\hline & 3 & 16 & 44.64 & & & \\
\hline & Total & 100 & & & & \\
\hline
\end{tabular}

$* p<0,05$

In Table 19, according to the results of the Kruskall Wallis homogeneity test conducted to compare the mothers' attitudes of child rearing in terms of the number of children, it was found that the dimensions of child-rearing attitudes which are child-rearing attitudes in terms of the number of children were not significantly different from those of the children who were democratic, authoritarian and overly tolerant $(p>0,05)$. The protective attitudes differ significantly according 
to the number of children; The democratic attitude scores of the mothers who had one child were found to be significantly higher than the other attitudes $(Z=6,964 ; \mathrm{p}<0,05)$. Mothers with one child were found to adopt a more protective attitude.

Table 20. Comparison of Child Raising Attitudes in Terms of Child Birth Sequence

\begin{tabular}{|c|c|c|c|c|c|c|}
\hline $\begin{array}{l}\text { Attitudes } \\
\text { Growing Children }\end{array}$ & $\begin{array}{l}\text { fRole } \\
\text { number }\end{array}$ & $\mathrm{N}$ & Average & $\mathrm{Z}$ & $\mathrm{sd}$ & $\mathrm{p}$ \\
\hline \multirow{4}{*}{ Democratic } & 1 & 33 & 52.58 & \multirow{4}{*}{4,572} & \multirow{4}{*}{2} & \multirow{4}{*}{, 102} \\
\hline & 2 & 53 & 53.25 & & & \\
\hline & 3 & 14 & 35.21 & & & \\
\hline & Total & 100 & & & & \\
\hline \multirow{4}{*}{ Protective } & 1 & 33 & 59.03 & \multirow{4}{*}{5,229} & \multirow{4}{*}{2} & \multirow{4}{*}{,073 } \\
\hline & 2 & 53 & 48.04 & & & \\
\hline & 3 & 14 & 39.71 & & & \\
\hline & Total & 100 & & & & \\
\hline \multirow{4}{*}{ Authoritarian } & 1 & 33 & 46.32 & \multirow{4}{*}{1,072} & \multirow{4}{*}{2} & \multirow{4}{*}{, 585} \\
\hline & 2 & 53 & 52.25 & & & \\
\hline & 3 & 14 & 53.75 & & & \\
\hline & Total & 100 & & & & \\
\hline \multirow{4}{*}{ Extremely tolerant } & 1 & 33 & 50.48 & \multirow{4}{*}{,080 } & \multirow{4}{*}{2} & \multirow{4}{*}{,961 } \\
\hline & 2 & 53 & 50.00 & & & \\
\hline & 3 & 14 & 52.43 & & & \\
\hline & Total & 100 & & & & \\
\hline
\end{tabular}

In Table 20, according to the results of the Kruskall Wallis homogeneity test conducted in order to compare mothers' child rearing attitudes in terms of child birth order variable, it was found that the dimensions of child rearing attitudes did not differ significantly in terms of child birth order variable. $(\mathrm{p}>0,05)$.

\section{Investigation of the Relationship between Child}

\section{Rearing Attitudes and the Attachment Styles of Mothers}

Eric Pearson Correlation was used in this study to investigate the correlation between child rearing attitude and attachment styles of the participants. For the correlation coefficients, the significance value was determined as 0.01 and 0.05 .

Table 21. Correlation Analysis Between Adult Attachment Models and Child Rearing Attitudes

\begin{tabular}{|c|c|c|c|c|c|c|c|}
\hline \multicolumn{2}{|c|}{ Research Variables $(\mathrm{N}=100)$} & 1 & 2 & 3 & 4 & 5 & 6 \\
\hline \multirow[t]{3}{*}{ 1. Avoidance } & $\mathrm{R}$ & 1 & & & & & \\
\hline & $\mathrm{P}$ & & & & & & \\
\hline & $\mathrm{N}$ & 100 & & & & & \\
\hline \multirow[t]{3}{*}{ 2. Anxiety } & $\mathrm{r}$ & $.487^{* *}$ & 1 & & & & \\
\hline & $\mathrm{P}$ & .000 & & & & & \\
\hline & $\mathrm{N}$ & 100 & 100 & & & & \\
\hline \multirow[t]{3}{*}{ 3. Democratic } & $\mathrm{R}$ & -.095 & -.092 & 1 & & & \\
\hline & $\mathrm{P}$ & .345 & .365 & & & & \\
\hline & $\mathrm{N}$ & 100 & 100 & 100 & & & \\
\hline \multirow[t]{3}{*}{ 4. Protective } & $\mathrm{R}$ & .169 & .046 & -.165 & 1 & & \\
\hline & $\mathrm{P}$ & .092 & .647 & .101 & & & \\
\hline & $\mathrm{N}$ & 100 & 100 & 100 & 100 & & \\
\hline \multirow[t]{3}{*}{ 5. authoritarian } & $\mathrm{R}$ & .189 & $.254^{*}$ & $-.227^{*}$ & $.454^{* *}$ & 1 & \\
\hline & $\mathrm{P}$ & .060 & .011 & .023 & .000 & & \\
\hline & $\mathrm{N}$ & 100 & 100 & 100 & 100 & 100 & \\
\hline \multirow[t]{3}{*}{ 6. Extremely tolerant } & $\mathrm{R}$ & .143 & .159 & $-.381^{* *}$ & $.552^{* *}$ & $.348^{* *}$ & 1 \\
\hline & $\mathrm{p}$ & .157 & .115 & .000 & .000 & .000 & \\
\hline & $\mathrm{N}$ & 100 & 100 & 100 & 100 & 100 & 100 \\
\hline
\end{tabular}

**. Meaningful at correlation level 0.01

*. Meaningless at correlation level 0.01 
dimension $(\mathrm{r}=.487 ; \mathrm{p}<0.01)$ were found to be moderately, positively and significantly related. The anxiety subscale and the authoritarian child rearing attitude $(\mathrm{r}=254, \mathrm{p}<0.05)$ were found to be weak, positive and significant. An authoritarian attitude $(\mathrm{r}=-, 227 ; \mathrm{p}<0.05)$ and an extremely tolerant attitude $(\mathrm{r}=-, 381 ; \mathrm{p}<0.01)$ were found to be negatively related to the democratic mile. An authoritarian attitude $(\mathrm{r}=.454 ; \mathrm{p}<0.05)$ and $\mathrm{a}$ highly tolerant attitude $(\mathrm{r}=.552 ; \mathrm{p}<0.01)$ were found to be positive and significant. The authoritarian attitude and the excessively tolerant attitude $(\mathrm{r}=348 ; \mathrm{p}<0.01)$ were found to be positively related and significant. Linear Regression Analysis sapt was applied to determine the predictive value of adult attachment styles and child rearing attitudes. Table 22 presents the findings of regression analysis:

Table 22. Descriptive Linear Regression Analysis with Attachment Attitudes of Attachment Styles

\begin{tabular}{|c|c|c|c|c|c|c|c|c|c|}
\hline & 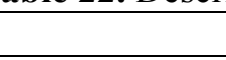 & \multicolumn{2}{|c|}{$\mathrm{R}^{2}=, 086$} & \multicolumn{3}{|l|}{$\mathrm{R}^{2}=, 048$} & \multirow[b]{2}{*}{$\begin{array}{l}\text { Zero- } \\
\text { order }\end{array}$} & \multirow[b]{2}{*}{ Partial } & \multirow[b]{2}{*}{ Part } \\
\hline \multicolumn{2}{|c|}{ Model } & B & Std. Hata & B & $\mathrm{t}$ & $\mathrm{p}$ & & & \\
\hline 1 & (Sabit) & 37,252 & 16,287 & & 2,287 &, 024 & & & \\
\hline & Democratic & ,013 & ,589 & ,002 &, 023 & ,982 &,- 092 &, 002 &, 002 \\
\hline & Protective &,- 842 & ,649 &,- 163 & $-1,296$ & ,198 &, 046 &,- 132 &,- 127 \\
\hline & Authoritarian & 1,723 &, 703 &, 274 & 2,449 &, $016 *$ &, 254 &, 244 &, 240 \\
\hline & $\begin{array}{l}\text { Extremely } \\
\text { tolerant }\end{array}$ & 1,202 & ,985 &, 154 & 1,219 &, 226 & , 159 &, 124 &, 120 \\
\hline
\end{tabular}

a. Dependent Variable: YiyeAnxiety sub-dimension $* \mathrm{p}<0,05$

In Table 22, according to the findings of adult attachment styles and explanatory regression analysis of child rearing attitudes, authoritarian attitude of child rearing $(\beta=0.27 ; \mathrm{p}<0.05)$, adult attachment styles significantly predict anxiety subscale. In addition, the explanatory analysis was found to be significant in approximately $5 \%$ of the participants.

\section{Discussion}

The aim of this study was to investigate the relationship between attachment styles of mothers who have children between 24-36 months with the socio-demographic variables. When the findings of the study were examined, there was a relationship between anxious attachment style and authoritarian attitude.

As a result of the research, it was found that parents who are anxiously connected have a more authoritarian attitude in their relationship with their children. Afşin and Özçelik (2018) found a finding in their study, and found that maternal attitude was significantly lower in children whose mothers were authoritarian than mothers who were tolerant. These results suggest that parents with anxious attachment style use nonfunctional defense mechanisms to overcome the negative emotions experienced by their children and to avoid confronting their children's feelings and their lack of communication. As a result, the authoritarian attitude they adopted in the relationship they had with their children came up with maladaptive behavior patterns. Kılıç and Kümbetlioğlu (2016) investigated the effect of attachment styles on communication skills. The individuals who developed unsafe attachment style showed that they did not have sufficient and effective communication skills because of the lack of confidence in the desired level of security, thus they showed negative behaviors in their social relations such as family, friends and marriages.

When we consider the tendency of parents who are anxiously connected to the authoritarian attitude in this context, adopting a form of relationship in which the control is shaped by their children by rules can be related to the desire to keep the relationship at a level where they feel safe. In this way, they reduce the uncertainty in the relationship and make it possible to achieve the goal of blocking alarming experiences. In this study, the study of the relationship between the attachment styles and personality traits of the mothers in the Manifest (2018) study showed that there was a significant relationship in the anxiety level sub-variable. According to this, it was determined that the anxiety level of mothers who had insecure attachment was higher. At the same time, mothers of children with insecure attachment had a more controlled personality. It is thought that mothers who attach unsafe mothers develop control behaviors in order to manage the anxiety they have had with their children and have an authoritarian attitude to strengthen their control behaviors.

Another remarkable finding in our study is that the higher attitudes of child rearing attitudes are higher in mothers reporting higher education level. Similar results are frequently encountered in the literature. For example, in the study of Aydoğdu (2016), it was found that the democratic attitudes of the associate degree graduates were 
significantly higher than those of the secondary school graduates. Alpoğuz (2014) also showed a result in his study and stated that as the education level increased, children's perceived parental democratic attitudes increased and the authoritarian attitude perception increased as the level of education decreased. Mothers with a high level of education can be considered to maintain their borders in close relationships, to express themselves comfortably in social environments, and to have a more democratic relationship system because of their ability to take responsibility and to make choices about their individual lives. It can be said that this form of relationship can bring democratic attitudes to the forefront in the approach of raising children. In addition, it is thought that mothers with high educational level are more willing to reach scientific knowledge by questioning traditional attitudes while raising children, thus increasing their awareness and positive attitudes.

Bornstein and Zlotnik (2008) found that mothers with a high level of education exhibit more childcentered attitudes when raising children. Recent studies have shown that close relationships and parental attitudes that are centered on the child's subjective presence and emotional needs shape the child's psychic structure. This process, which started with child psychoanalysis, was strengthened by the use of the game in psychotherapy and is now the basis of many games therapy schools (Bakhshandeh et al, 2015; Gil et al, 2017; Upikang, 2017; Eissazadeh et al, 2019). It seems inevitable that educated parents who are interested in this subject will reach this information. Parents who have high levels of education are expected to adopt a democratic attitude and a child-centered relationship. It is seen that psychoeducation to be done to families is very important in this sense. As a matter of fact, in the study of Şimşek (2017), the families were taken into the $7-19$ years old family education program and stated that the family attitudes change in a positive way, they are more positive towards their children and they decrease their negative attitudes in the families who completed the training. In a similar study, Landy and Menna (2006) found in their study that the parents' selfefficacy of the families participating in the training at the end of the family education for the families of offensive and incompatible children was a significant difference compared to the control group. From this point of view, it can be thought that increasing the mother's self-efficacy decreases concerns about raising children and increases their democratic attitudes. Kaya (1994) in their study, parents' child care and education related to the provision of education by reducing their concerns, feel better, authoritarian attitudes towards children, increased democratic attitudes and improved children's negative behavior has led to improvements. It has been observed that they have adopted a more conscious child-rearing approach by increasing their knowledge levels and strengthening their behaved behaviors. It is thought that knowledge-based attitudes of parents with increasing awareness levels also reveal a relationship system with democratic characteristics.

According to the income level variable, anxiety was higher in mothers who reported low income level. It can be thought that this situation is due to the anxiety which may arise from the negative experiences that can be seen with the economic conditions. Şanlı (2007) and Dursun (2010) found that as the income level of the family decreases, the inconsistency of the mother has increased. It is thought that the mother's financial concerns cause conflicts within the family and these concerns affect the style of attachment to both the spouse and the child. According to Brown and colleagues (2017), few studies have examined the impact of maternal attitudes on the formation of later attachment models among low-income and ethnic minority school-age children. In this study, sensitive maternal care in infancy was not associated with insecure attachment. However, it was found that mothers with insecure attachment had more aggressive attitudes during infancy and showed behaviors containing a scattered attachment pattern in middle childhood. This result supports our findings regarding the development of anxious attachment style of mothers with low income.

Erkan and Toran (2004), in their research with mothers who have children at the age of 5 years, as the monthly income of the family increased the rejection of children's rejection, the decline in child found that the income level increased. It is thought that child rejection will be seen in mothers with insecure attachment style. It is estimated that the income level of the family is a cycle that will be transferred from generation to generation between the anxious attachment style of the mother. In this cycle, child rejection is a result.

\section{Conclusion}

According to the results of the research, it will be useful to increase the education level of mothers and to raise awareness about attachment styles. In order to increase the educational level of the mothers, it would be beneficial to increase the necessary measures for the completion of the compulsory education process in the formal education institutions, and to support the disadvantaged regions and students socially and economically in order to reduce the dropout. It is important that a compulsory education should be 
carried out as a policy of the state, including issues such as close family relationships, child development and child rearing attitudes, emotion management and attachment types, in order to enable couples to form a more conscious and healthy family system before marriage. In addition to formal trainings, it is useful to conduct awareness-raising activities that will contribute to the personal development of the parents to review their emotions, thoughts and behaviors at regular intervals. In addition, the first stage of attachment styles in health institutions and municipalities can be offered in psychological counseling centers and psychological counseling / psychotherapy services before the marriage of emotional lives and problems related to family relationships have gained awareness of their relationship with their children after having serious problems in the relationship, have insecure attachment style the creation of institutions in which parents can receive psychological support in order to create transformations in their inner world will be useful. The fact that the current research sample measured mothers' attachment style and child rearing attitudes prevented us from knowing the effects of fathers on this issue. For this reason, it is recommended that researchers who will conduct research on this subject, including fathers. In addition, conducting a study involving children's attachment style will enable us to obtain more objective data.

The results of the study showed that mothers' anxious attachment styles lead to authoritarian attitudes. It is recommended that clinicians working with children should support the behavior of the children in the perspective of attachment styles of the children and child rearing attitudes, and support the mother with the psychoeducation studies.
Research, 3(1), 10-13.

Baykalova, E. D., Artyna, M. K., Dorzhu, N. S., Ochur, T. K., \& Mongush, D. S. (2018). Morphological interference in the process of mastering English speech in conditions of interaction of Tuvan, Russian and English as a foreign language. Opción, 34(85-2), 35-60.

Ceisil, U., E-Awareness of University Student through Smart Phones and Developing Social Networks. Journal of Humanities Insights, 2018. 02(03): p. 139145 .

Chacon, D. D. A., Araújo-Filho, I., VillarimNeto, A., Rêgo, A. C. M., Azevedo, I. M., Bernardo-Filho, M., ... \& Medeiros, A. C. (2007). Biodistribution of the radiophamarceutical sodium pertechnetate (Na99mTcO4) after massive small bowel resection in rats. Acta cirurgicabrasileira, 22(6), 430-435.

Eripek, S: (1989). Alt özel șinif ögrencilerinin ilk okul sinıfları düzeyinde sesli okuma basarılarının değerlendirilmesi. EğitimFakültesiDergisi, 2 , 125-140.

Feresin, C., \& Močinić, S. (2017). DO WE NEED TO TRAIN TEACHERS AND STUDENTS TO CARE ABOUT OTHER LIVING BEINGS? Humanities \& Social Sciences Reviews, 5(1), 33-45. https://doi.org/10.18510/hssr.2017.513

Kumar, S. and V. Gapta, Advantages and Disadvantages of Social Websites on Young Students. Journal of Humanities Insights, 2017. 01(01): p. 34-36.

Margalit, M., \&Raviv, A. (1984). LDs' expressions of anxiety in terms of minor somatic complaints. Journal of Learning Disabilities, 17(4), 226-228.

Mendi, A., Köse, S., Uçkan, D., Akca, G., Yilmaz, D., Aral, L., ... \&Uçkan, S. (2016). Lactobacillus rhamnosus could inhibit Porphyromonasgingivalis derived CXCL8 attenuation. Journal of Applied Oral Science, 24(1), 67-75.

Mohammad, I., Importance of Supervisory in Educational Progress of PhD Students. Journal of Humanities Insights, 2017. 01(02): p. 76-88.

Mostafavi, S.M., 3D Graphene Biocatalysts for Development of Enzymatic Biofuel Cells: A Short Review. Journal of Nanoanalysis, 2015. 2(2): p. 57-62.

Aida Badamchi Shabestari, S.M.M., Hanieh Malekzadeh, Force
Comparative Study on Biosimilar Adalimumab and Humira. Revista Latinoamericana de Hipertensión, 2019. 13(06): p. 496-509.

Ainsworth, M. S. (1989). Attachments beyond infancy. American psychologist, 44(4), 709.

Algan, A. G., \&Șendil, G. (2013). Okul öncesi cocuklar ve ebeveynlerinin bağlanma güvenlikleri ile çocuk yetisstirme tutumları arasındaki ilişkiler. Psikoloji Çalışmaları/Studies in Psychology, 33(1), 55-68.

Bakhshandeh, M. Sedrposhan, N., \& Zarei, H. (2015). The Effectiveness of CognitiveBehavioral Group Counseling to Reduce Anxiety, Marriage; Single People have to be Married in Esfahan City (2013-2014). UCT Journal of Social Sciences and Humanities
Özden, M. Y. (2017). A validity and reliability study of the computational thinking scales (CTS). Computers in Human Behavior, 72, 558-569.

Samira Eissazadeh, M.P. and S.M. Mostafavi, Measurement of Some Amino Acid Using Biosensors Based on SiliconBased Carbon Nanotubes. Journal of Computational and Theoretical Nanoscience, 2019. 16: p. 1

Samira Eissazadeh, M.P., Mohammad Sadegh Taskhiri and S.M. Mostafavi, Improvement of Sensitivity of AntigenAntibody Detection of Semen Through Gold

Nanoparticle. Research Journal of Pharmaceutical, Biological and Chemical

Selçuk, E., Günaydın, G., Sümer, N., \&Uysal, Ä. (2005). Yetişkin bağlanma Sciences, 2019. 10(1): p. 144. 
boyutları için yeni bir ölçüm: Yakın ilişkilerde yaşantılar envanteri-II'nin Türk örnekleminde psikometrik acıdan değerlendirilmesi. Türk Psikoloji Yazılart, 8(16), 1-11.

Soysal, A. Ş., Bodur, Ș., İşeri, E., \&Şenol, S. (2005). Bẻbeklik dơnemindeki bağlanma sürecine genel bir bakıș. Klinik Psikiyatri, 8(2), 88-99.

Sümer, N., Say1, M., veBerument, SK (2016). Anne duyarlılığ́ ve çocuklarda bağlanma (1. Bask1). Istanbul: Koç Universitesi Yayınlarl.

Tahiroğlu, A. Y., Bahalı, K., Avcı, A., Seydaoğlu, G., \&Üzel, M.'(2009). Ailedekí disiplin yöntemleri, demografik özellikler ve cocuklardaki davranıs sorunları arasındaki iliş̧ki. Çocuk ve Gençlik Ruh Sağllğ Dergisi, 16(2), 67-82.

Upikang, B., Summative Evaluation of Teacher Performance by Secondary School Students. Journal of Humanities Insights, 2017. 01(02): p. 63-75.

Villalobos Antúnez, J. V., \& Bello, M (2014, October). Etica para una sociedad global: la bioética puente para el giro tecnocientífico. In Congreso Iberoamericano de Bioética e Investigación. Corporación Universitaria Lasallista. 